"A practical study on evaluation of sales and service potential in distributing the industrial products (case study: regions in Ukraine)"

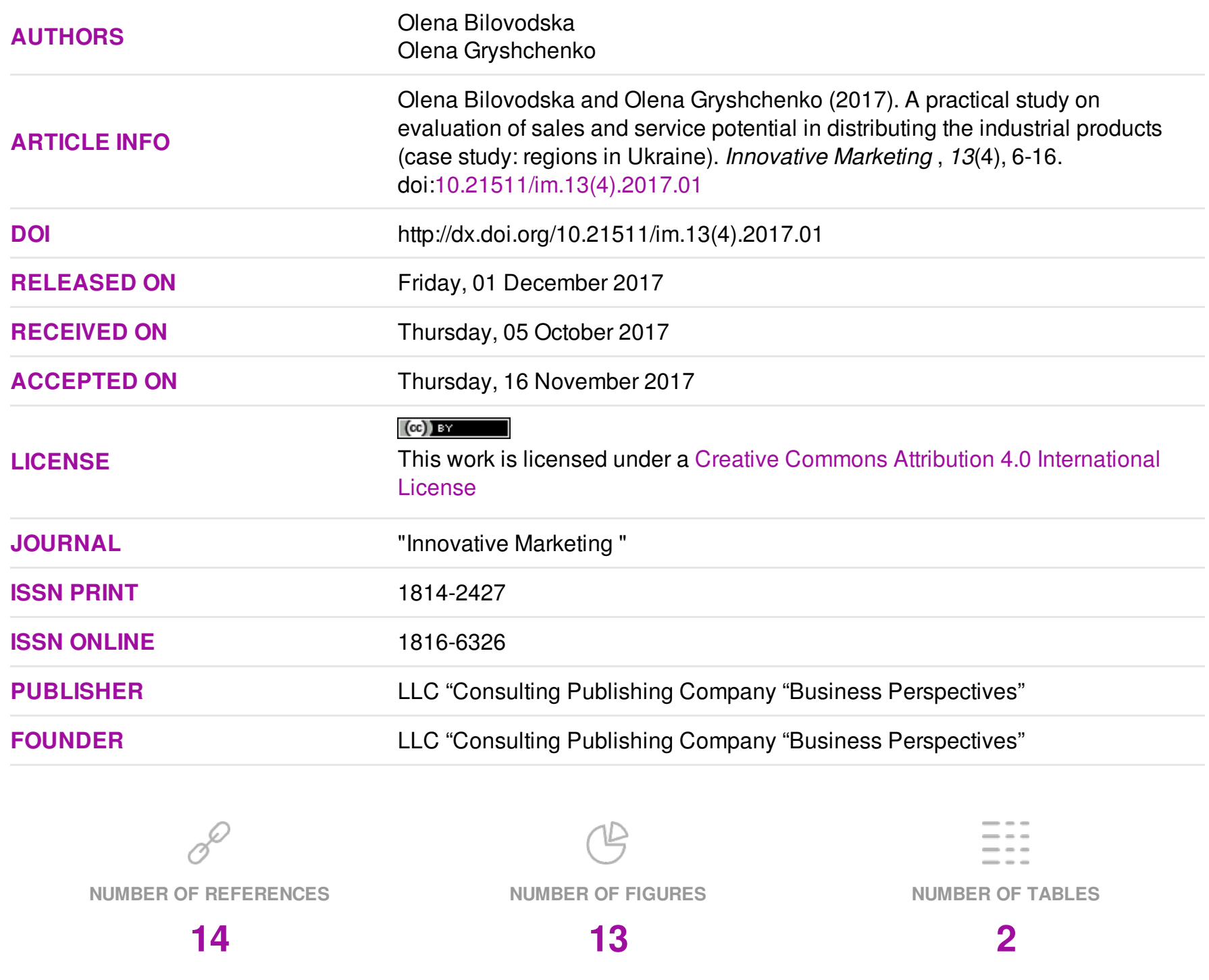

(C) The author(s) 2023. This publication is an open access article. 
Olena Bilovodska (Ukraine), Olena Gryshchenko (Ukraine)

\title{
A practical study on evaluation of sales and service potentials in distributing the industrial products (case study: regions in Ukraine)
}

\begin{abstract}
The article covers the study of sales and service potentials of Ukrainian regions in distributing the industrial products. Using the data of the State Statistics Service of Ukraine, the statistical analysis of key indicators of sales and service potentials is provided. The analysis of indicators' dynamics in 2010-2015 shows the stability or insignificant increase in almost all regions. Based on ranking results of Ukrainian regions for sales and service potentials, the five-zone matrix of potentials is formed. The evaluations show that Kyiv (city), Dnipropetrovsk and Donetsk regions can be defined as leaders, and Chernivtsi and Ternopil regions can be defined as outsiders. High concentration of regions in pessimistic zones of the five-zone matrix of potentials indicates the crisis processes in the country. This also defines the high degree of regional disparities and contradictions in service and sales activities in Ukraine.
\end{abstract}

Keywords: region, potential, sales potential, service potential, ranking, regional disparities.

JEL Classification: O10, P25, R11.

Received on: $5^{\text {th }}$ of October, 2017.

Accepted on: $16^{\text {th }}$ of November, 2017.

\section{Introduction}

Economic growth is one of the priority tasks facing Ukraine and its regions at present. The studies of foreign and domestic scientists show that only innovative development of the national economy and the efficient use of the newest technologies are able to provide long-term economic growth. The authors do not deny the importance and, in most cases, the exclusive role of innovative development. But the authors also see it expedient to note that the innovative development requires high concentrations of material, intellectual and financial resources but also providing relevant level of service and sales potentials.

\section{Literature review}

Problems of improvement and management of the potential of the region are observed by many scientists. Scientific research in this field presents different views. Scientific works of Balatskiy (2006, 2010), Libabova and Khvesyk (2014), Semenova and Rudenko (2012), Grishyna, Efimova, and Grishina (2011), Gedz (2012), Tuleja and Gajdová (2015), Low, Henderson, and Weiler (2005) are devoted to the study of the economic potential of the region.

In the structure of the region's potential, Balatskiy $(2006,2010)$ has determined the following components: institutional potential, labor potential, financial potential (current finances and investments), production potential, intellectual potential, natural potential, social potential,

(C) Limited Liability Company "Consulting Publishing Company "Business Perspectives", 2017.

Olena Bilovodska, Ph.D. in Economics, Associate Professor, Associate Professor of the Department of Marketing and MIA, Sumy State University, Sumy, Ukraine.

Olena Gryshchenko, Ph.D. in Economics, Associate Professor of the Department of Marketing and MIA, Sumy State University, Sumy, Ukraine. managerial potential, the potential of the regional infrastructure.

Libabova and Khvesyk (2014) investigate the current state, trends and problems of reproduction of the socio-economic potential of sustainable development of Ukraine and its regions. The authors have suggested the methodology to form the system of indicators of the effectiveness of the development of regional socio-economic systems.

Semenova and Rudenko (2012) consider region's economic potential as a system, the main subsystems of which are investment, innovation, natural resource and labor potentials, characterized by appropriate economic resources. The criteria for its assessment include: the number of economically active population in the region, natural resources of the region of production purpose, fixed assets (production and non-production purposes), stocks of objects of industrial purpose and objects of durable use, intangible resources.

Grishyna, Efimova, and Grishina (2011) note that the region's economic potential is the total available capacity of economic resources within the region to ensure the production of the maximum possible amount of goods and services that meet the needs of society at this stage of its development. The volume of economic potential is determined by the quantity and quality of available economic resources, as well as conditions that ensure their effective use. The authors point out that economic potential should be seen as a system which contains a certain number of components such as investment potential, innovative potential, production potential and labor potential.

According to Gedz (2012), the potential of region's socio-economic development characterizes the possibility of its development by using the whole complex of territorial resources, features of the 
existing and perspective structure of its economy, geographical position in the interests of improving the population's quality of life.

Tuleja and Gajdová (2015) have evaluated the economic potential of the regions of the Czech Republic using the following indicators: the regional gross domestic product per capita, the net available income of household per person, the gross fixed capital per inhabitant, the unemployment rate and an amount of compensation of employees.

Low, Henderson, and Weiler (2005) have provided the practical study on gauging a region's entrepreneurial potential. They point to the old rules collapse, where traditional assets such as cheap land and labor determined a region's success or failure. Instead, new categories of assets are shaping economic prospects - assets like workforce skills, lifestyle amenities, access to capital and information, and innovative activity. The mission for us is to find new pathways to tap these assets.

On the other hand, Teslya and Shults (2014), Maksimova (2009), Fedotov (2007) deal with the market potential and point to its key role due to a number of issues for the domestic economy.

Teslya and Shults (2014) believe that the market potential of the region is a part of its economic potential. They also see market potential as a separate set of interconnected elements of its economic system, allocated on the basis of the function performed by them on the market, characterizing the region's ability to make production and consumption opportunities. The authors state that market potential consists of four structural elements: market infrastructure, innovative potential, consumer potential, and industrial potential. The formation of market potential is influenced by the priorities of national economic policy regarding the development of the production, business support, creating conditions for activation of innovation activity on production, improvement of investment climate and the effectiveness of investment projects, as well as the income, which determines their purchasing power.

In Maksimova (2009), the region's market potential is considered as a separate set of interrelated elements of the economic system in the region, describing the ability of the region to implement production and to meet the challenges of economic and social development.

According to Fedotov (2007), the analysis of the region's market potential is not limited to the definition of the capacity of the regional market, since there are many factors that can influence the adoption of managerial decisions on the regulation of economic processes in the region (i.e., legislation, the capacity of the business activity among the population, etc.). The market potential is always determined by the number of the population and average income per capita (in the dynamics on the types of consumer goods and services).

The research by Bilovodska et al. (2017) covers the analytical study on logistics outsourcing impact on logistical service quality in supply chains. Authors have provided a research of enterprises service capabilities and have formed a set of indicators to estimate the logistics service level of enterprise. This study provides the essentials for management of service and sales activities. On the other hand, Olefirenko and Shevliuga (2017) have analyzed the indicators and characteristics of sales policy instruments of enterprises and have estimated the influence of sales policy parameters on innovation level. In this context, we believe that the effective service and sales management of the enterprises is the key factor for sustainable growth and it influences the region's rankings for service and sales potentials.

Despite the fact that a lot of works are devoted to research of the components and dimensions of the potential of the regions, many approaches to region's potential management are developed, the ultimate consensus between scientists and economists is not achieved. Therefore, there is a need for a more detailed study and assessment of the region's service and sales potentials. This will lead to the development of relevant approaches to their management.

\section{Aim of the study}

The object of the article is to provide the study of service and sales potentials of Ukrainian regions in distributing the industrial products using the official statistic data of the State Statistics Service of Ukraine. Results based on this assessment are aimed at defining the degree of regional disparities in Ukraine.

\section{Results}

According to the author's vision, the sales potential of the regions in the distribution of industrial products covers the actual and potentially possible sales volumes, which, in turn, depend on the demand for goods, the general market conditions, business trends, income level and business activity. To provide the analysis of the Ukrainian regions' sales potential, it would be appropriate to use the following indicators: gross regional product (GRP), output of products and services, sales volume for industrial products (total industrial output), retail 
and wholesale trade turnover. The analysis of indicators' dynamics in 2010-2015 shows an increase in their value in each region (except
Donetsk and Luhansk regions). On top of all, the special attention should be paid to the 2015 when the indicators have rapidly increased (Figures 1-7).

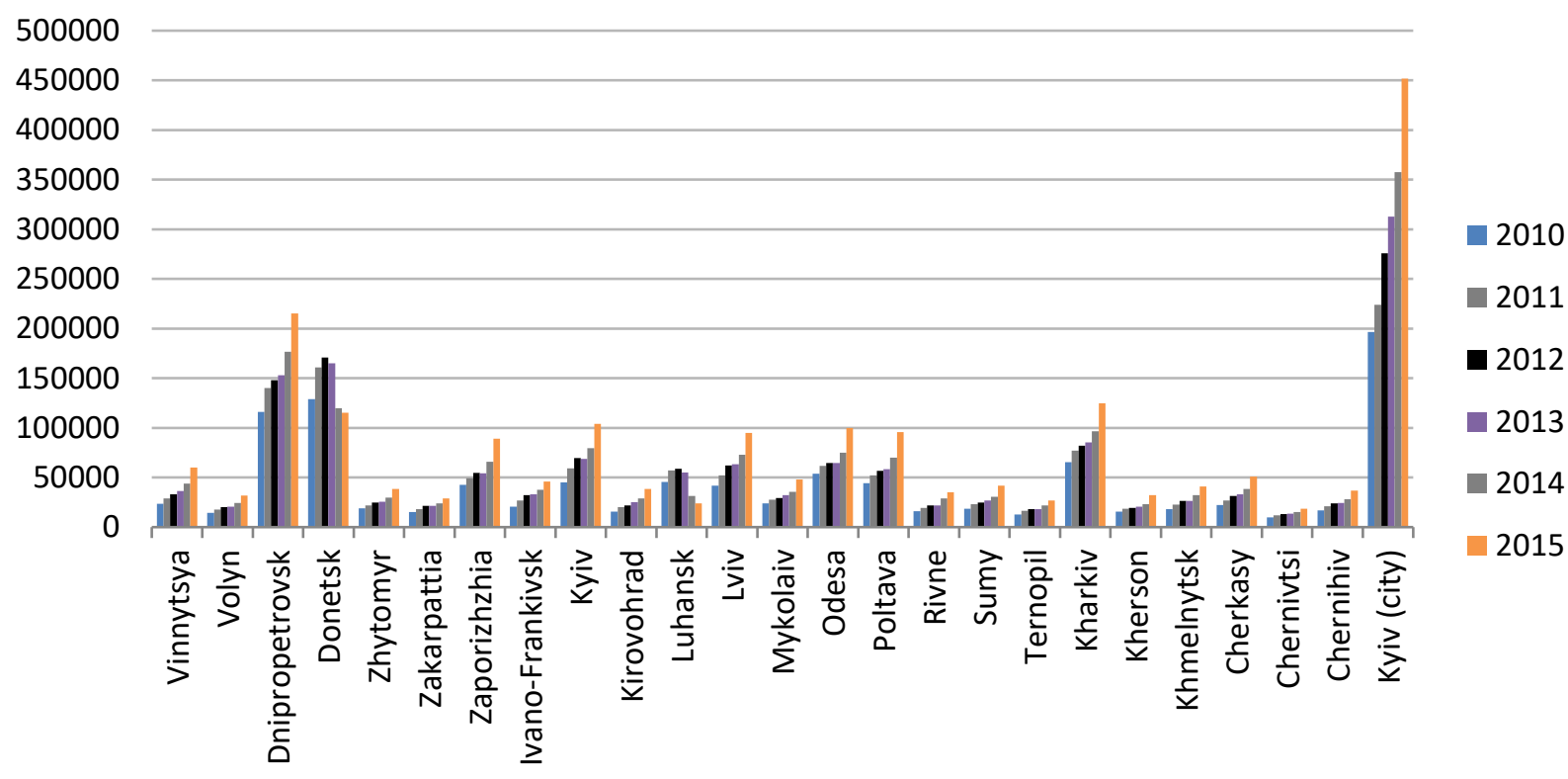

Fig. 1. The GRP by region in 2010-2015, million UAH at actual prices (based on data of the State Statistics Service of Ukraine)

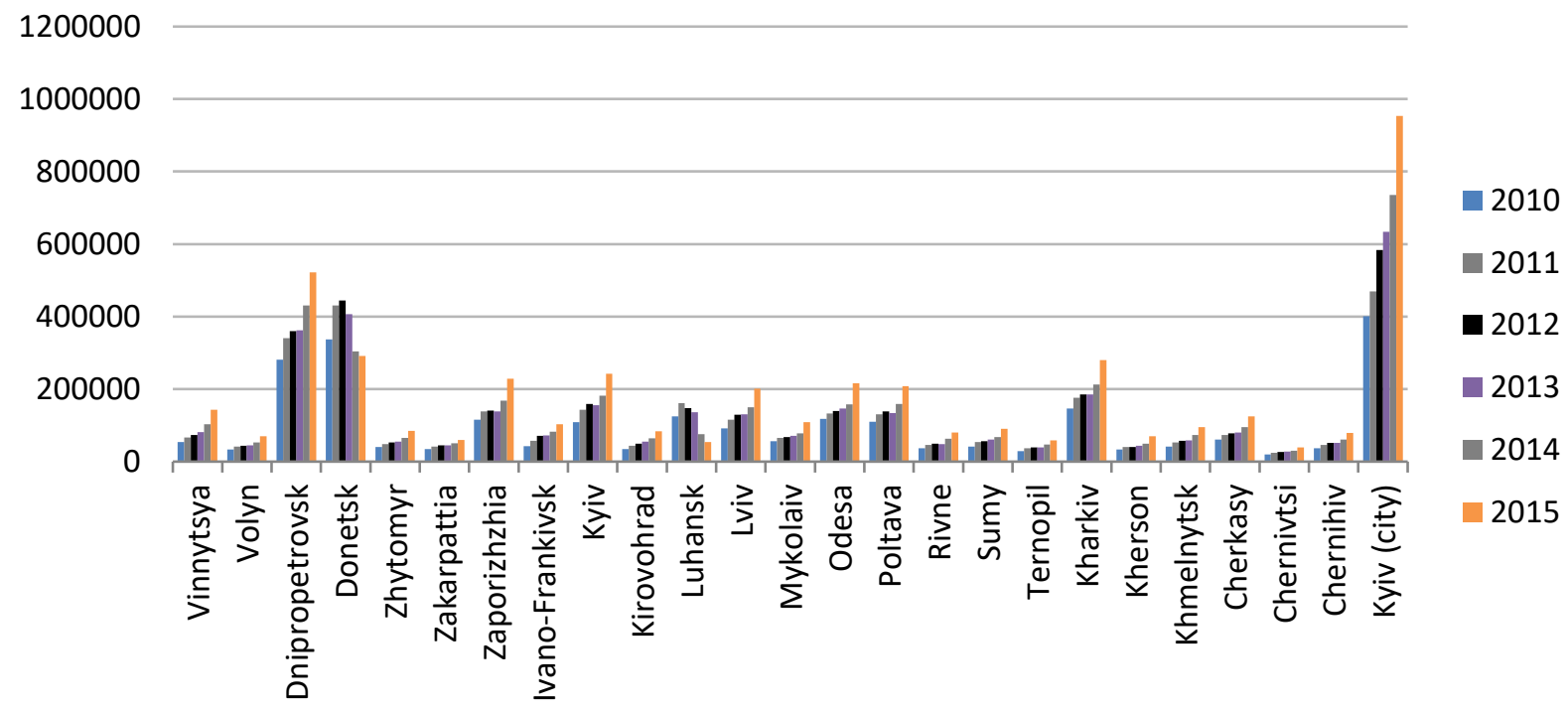

Fig. 2. The output of products and services in Ukrainian regions in 2010-2015, million UAH at actual prices (based on data of the State Statistics Service of Ukraine) 


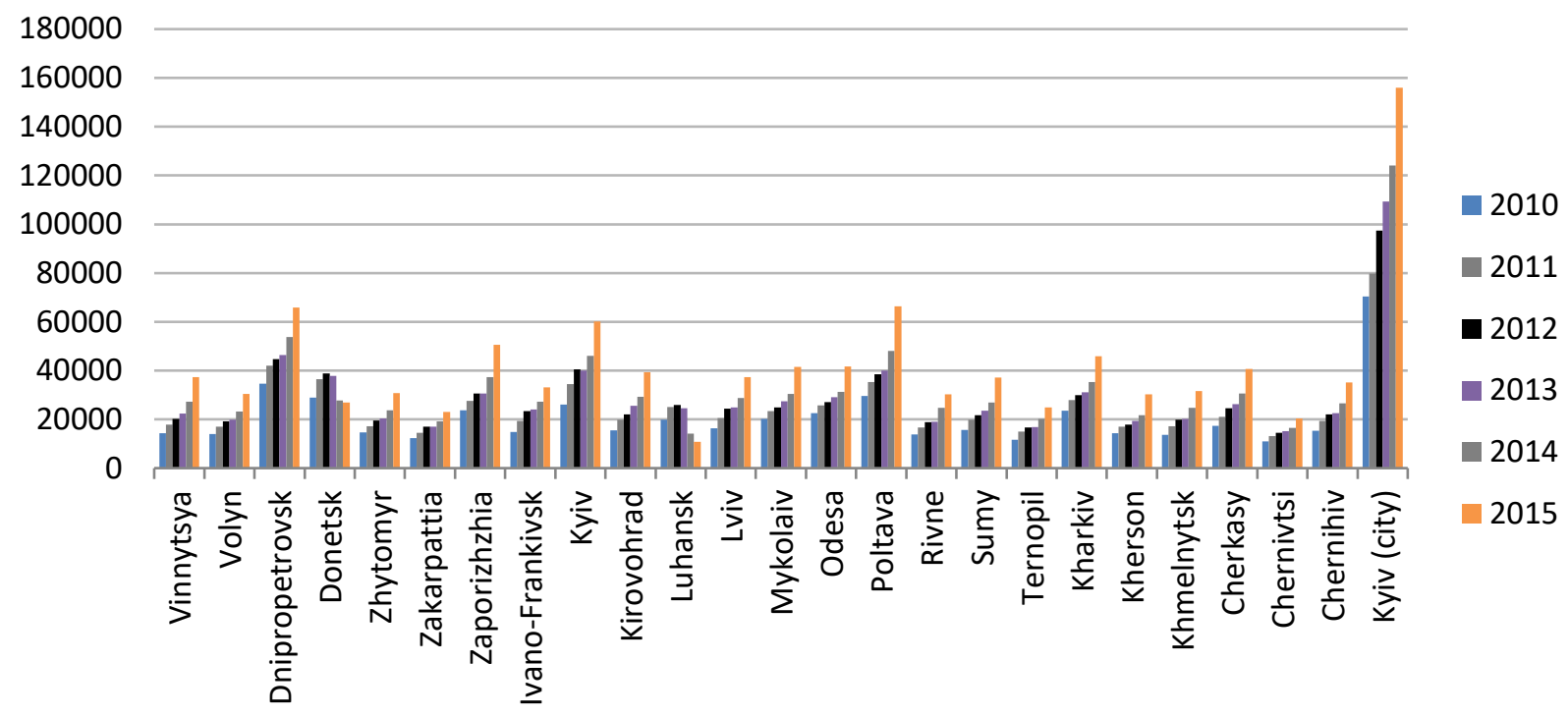

Fig. 3. The GRP per capita by region in 2010-2015, UAH million (based on data of the State Statistics Service of Ukraine)

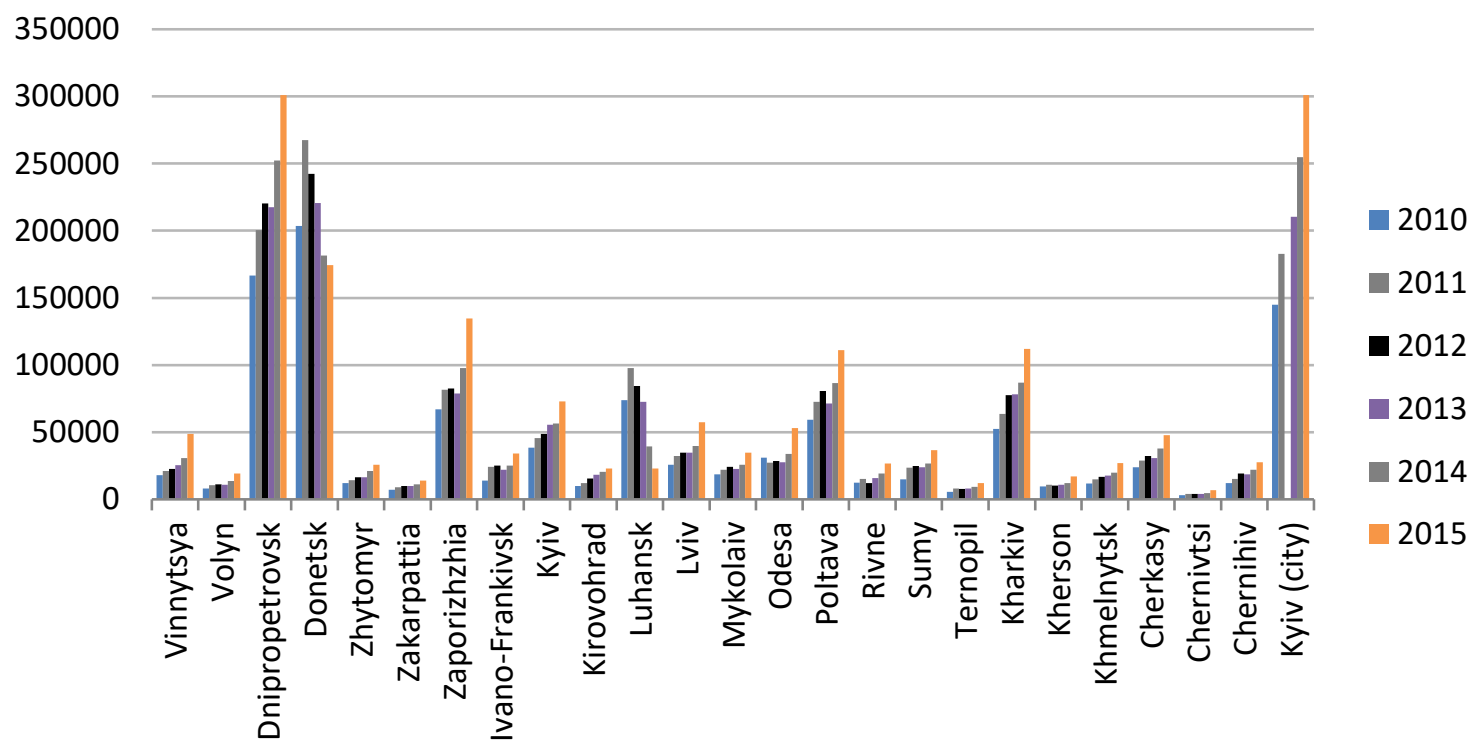

Fig. 4. The sales volume for industrial products (goods, services) by region in 2010-2015, million UAH (based on data of the State Statistics Service of Ukraine)

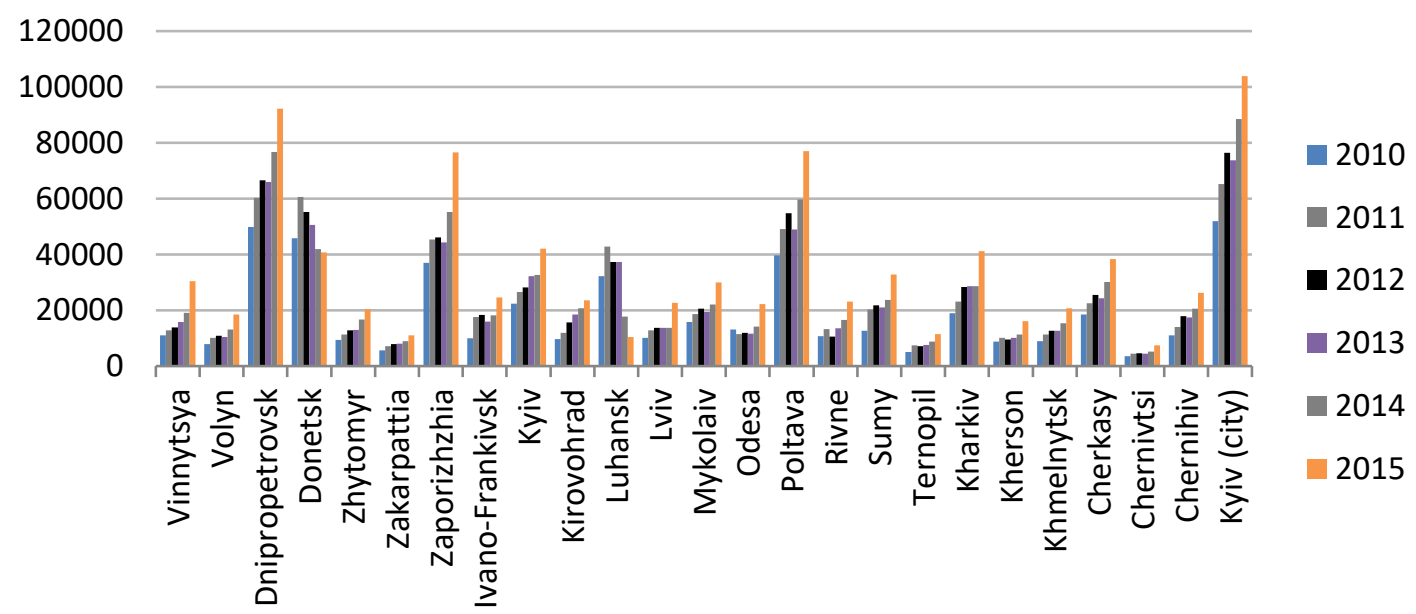

Fig. 5. The per capita sales volume for industrial products (goods, services) by region in 2010-2015, million UAH (based on data of the State Statistics Service of Ukraine) 


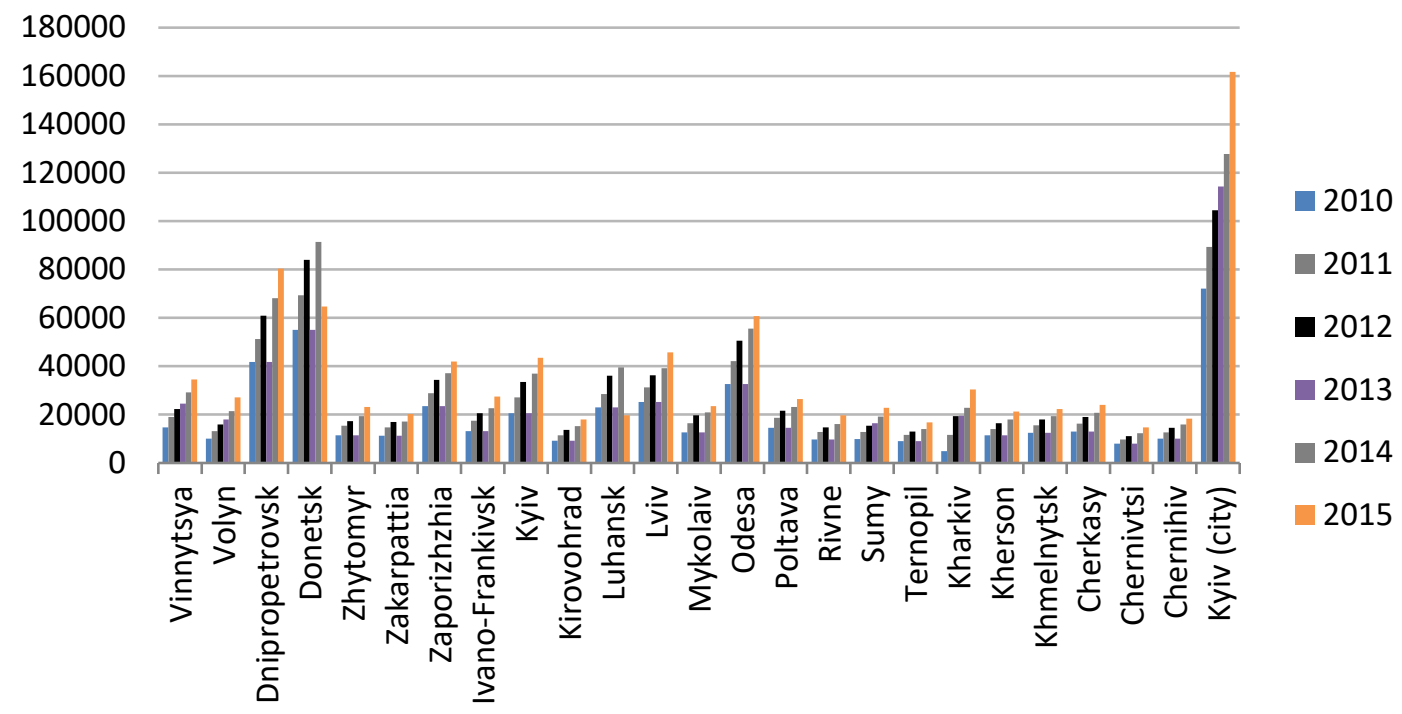

Fig. 6. The retail trade turnover by region in 2010-2015, million UAH (based on data of the State Statistics Service of Ukraine)

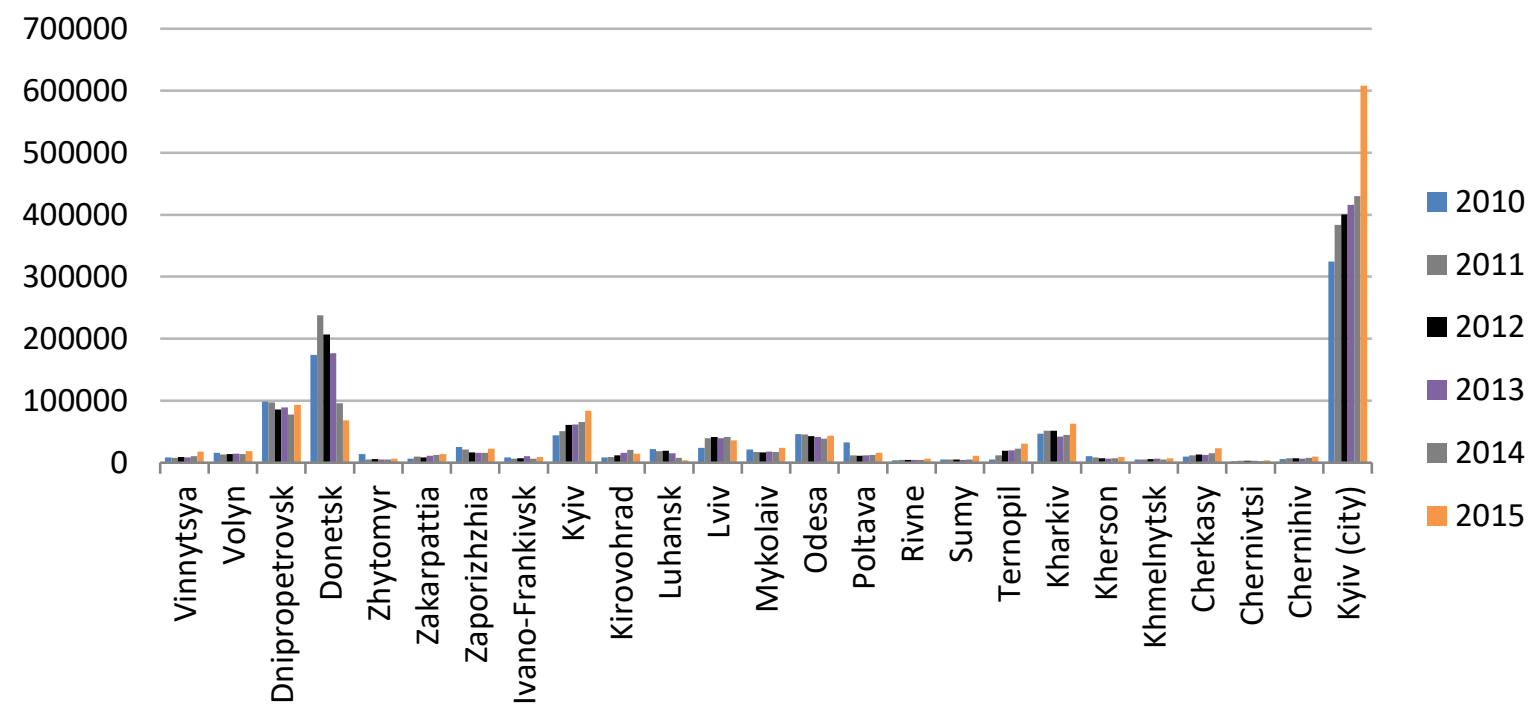

Fig. 7. The wholesale trade turnover by region in 2010-2015, million UAH (based on data of the State Statistics Service of Ukraine)

As we see from the diagrams above for the overwhelming majority of the evaluating indicators, the leaders are the Kyiv (city), Dnipropetrovsk and Donetsk regions. Although it should be noted that Poltava region is the leader in GRP and in the per capita sales volume for industrial products (goods, services).

To determine the ranking of Ukrainian regions for sales potential, it was decided to calculate the average values of its indicators for the analyzed period (see Table 1 in Appendix).

Thus, according to the ranking results of the Ukrainian regions in terms of the level of development of sales potential, the leaders are the Kyiv (city), Dnipropetrovsk and Donetsk regions (Table 1, lines marked in green), while Chernivtsi, Ternopil and Zakarpattia regions are outsiders (Table 1 , lines marked in red).

When distributing industrial products, the service potential brings together intermediaries (the number of enterprises, both industry and services sector), sales volume for services, etc. The dynamics of service potential indicators by regions of Ukraine in 2010-2015 is shown in Figures 8-12. The relative stability with a tendency to a slight increase can be traced for all regions (except Kyiv (city), and Donetsk, Luhansk, Kharkiv regions). 


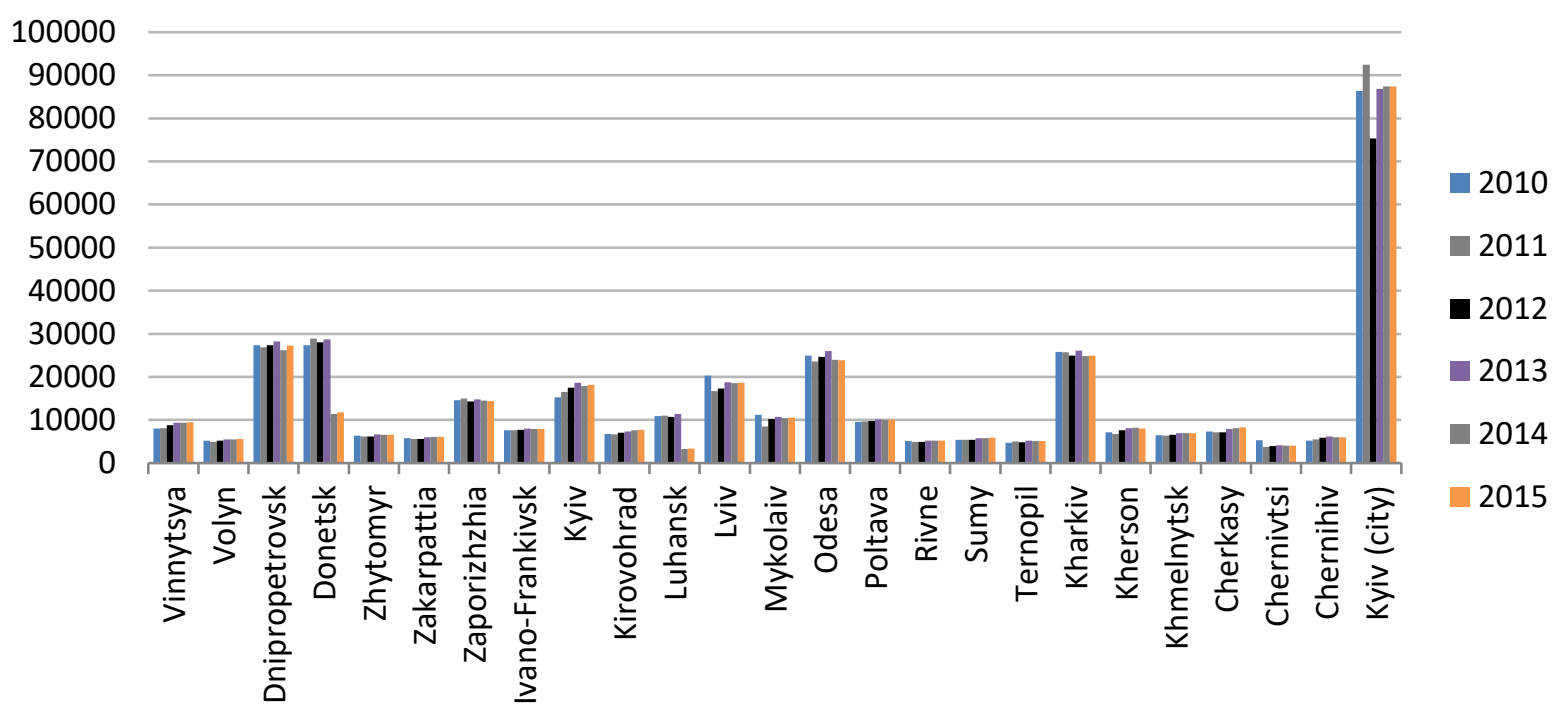

Fig. 8. The number of enterprises by region in 2010-2015, units (based on data of the State Statistics Service of Ukraine)

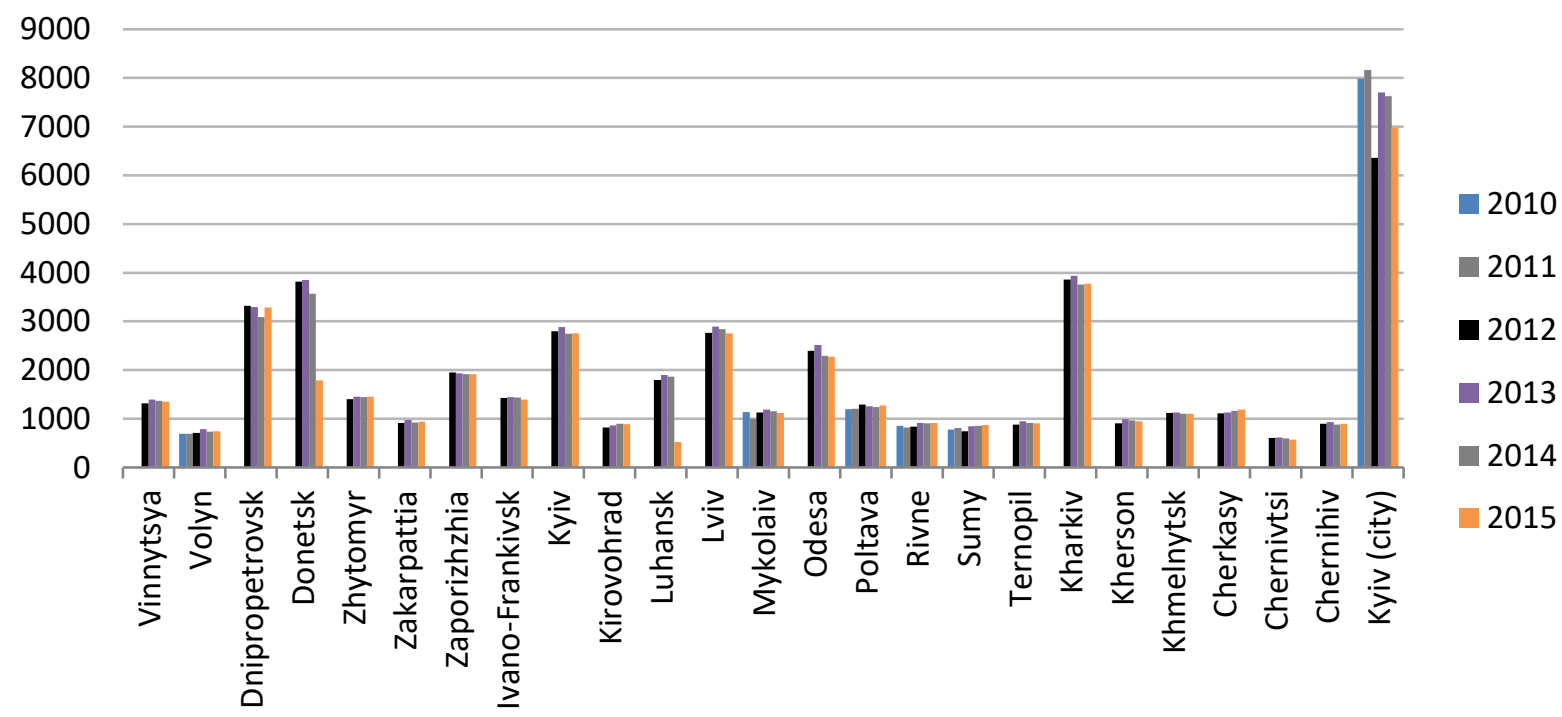

Fig. 9. The number of industrial enterprises by region in 2010-2015, units (based on data of the State Statistics Service of Ukraine)

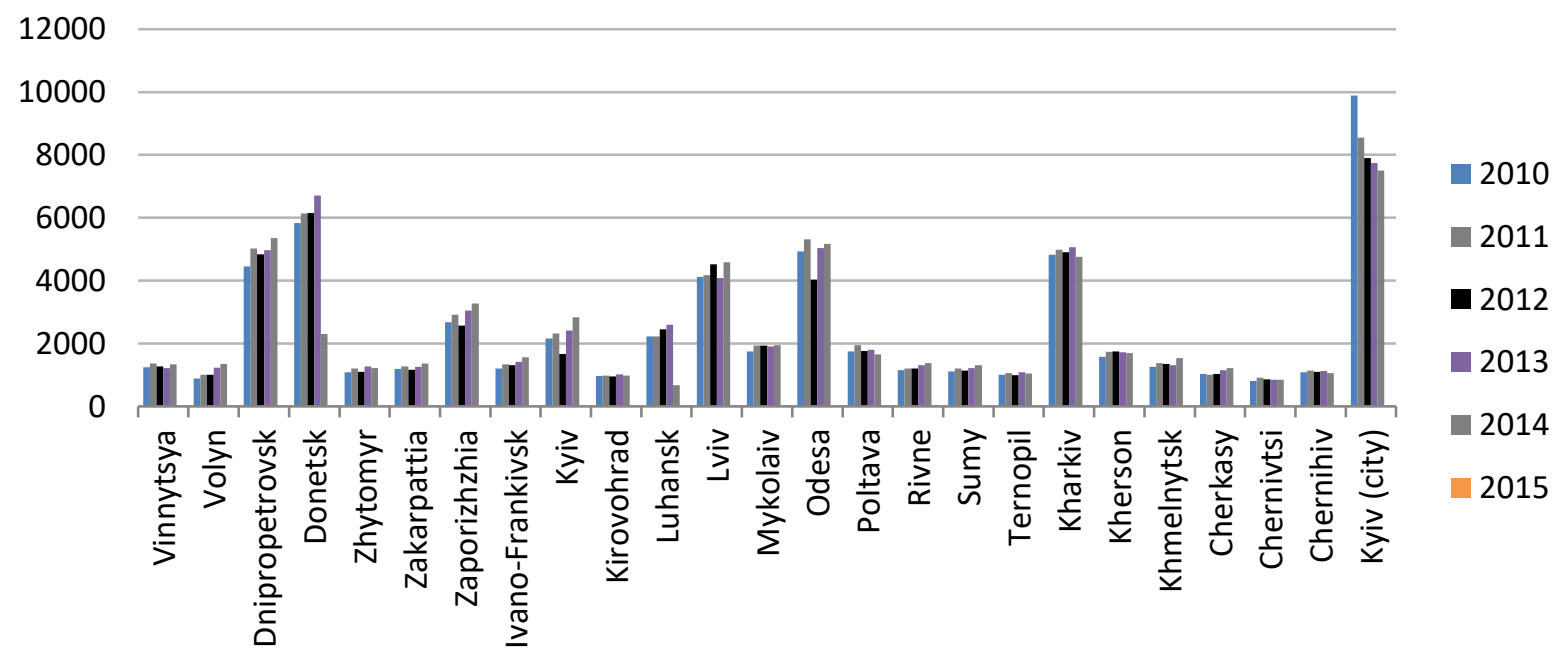

Fig. 10. The number of services sector enterprises by region in 2010-2015, units (based on data of the State Statistics Service of Ukraine) 


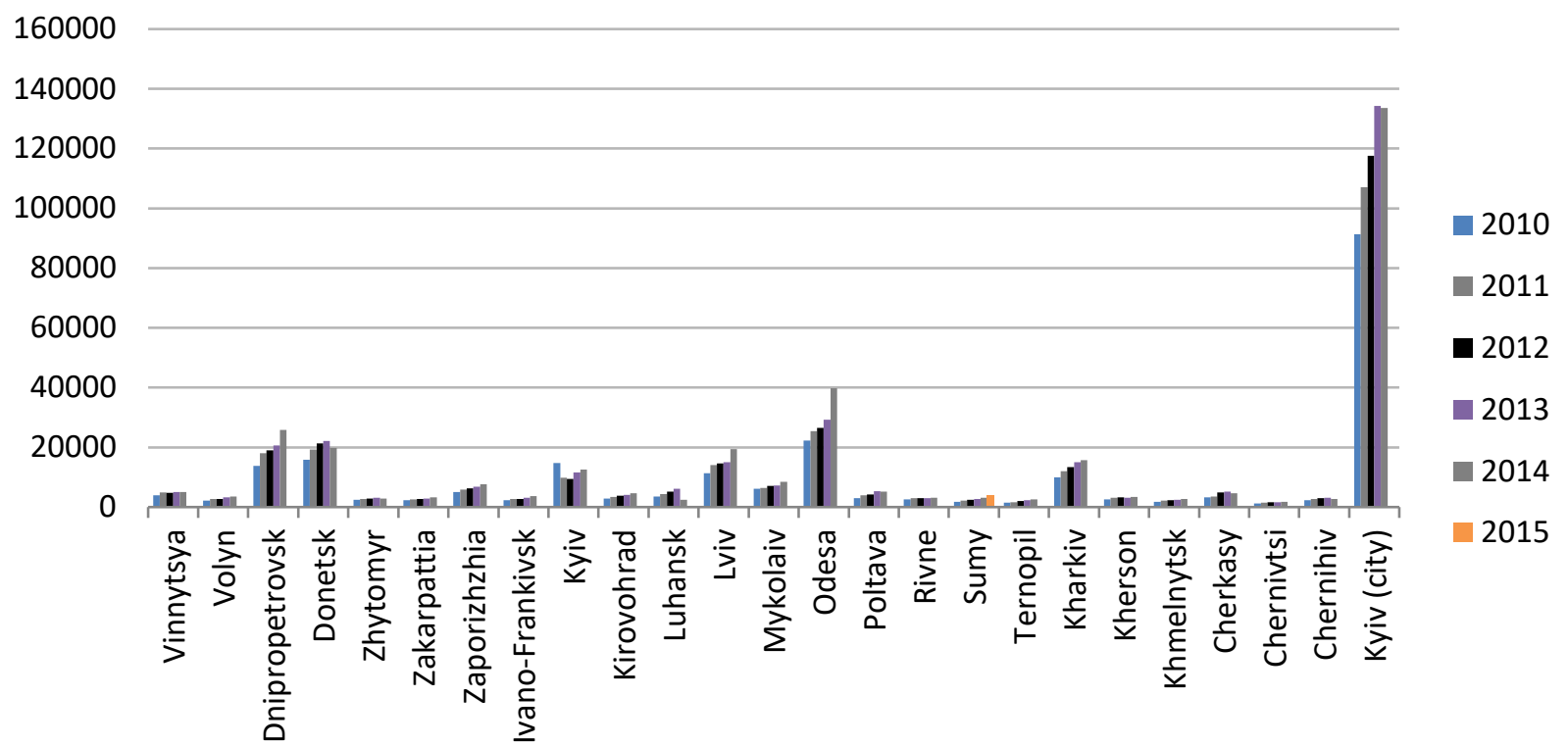

Fig. 11. The sales volume of services sector enterprises by regions in 2010-2015, million UAH (based on data of the State Statistics Service of Ukraine)

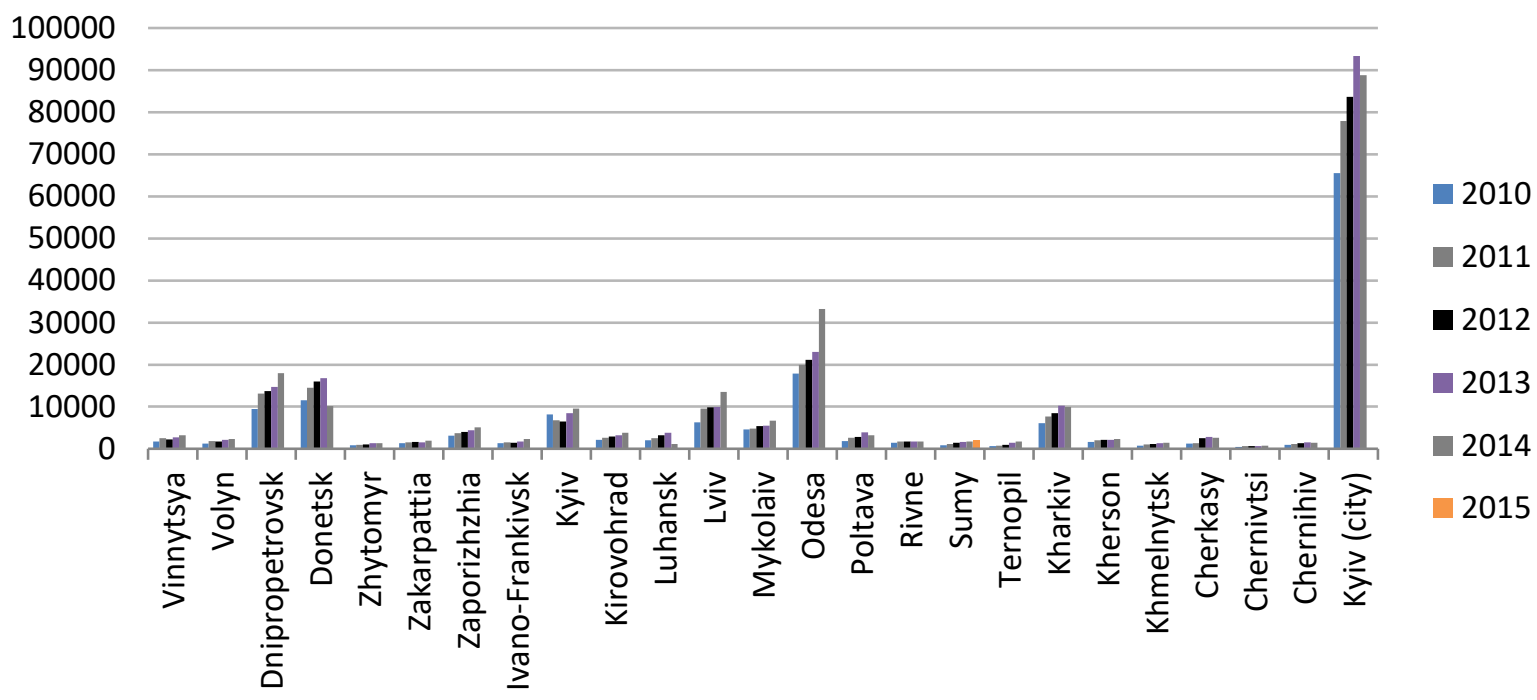

Fig. 12. The volume of services sold by the services sector enterprises to enterprises by regions in 2010-2015, million UAH (based on data of the State Statistics Service of Ukraine)

As we see from the diagrams above, the leadership on the total number of enterprises is observed in Kyiv (city), Dnipropetrovsk and Kharkiv regions; the leadership on the number of industrial enterprises is observed Kyiv (city), Kharkiv and Donetsk regions; the leadership on the number of services sector enterprises is observed in Kyiv (city), Donetsk and Dnipropetrovsk regions. The top values of sales volume of services sector enterprises were indicated for Kyiv (city), Odesa and Donetsk regions. In addition, Kyiv (city), Odesa and Dnipropetrovsk regions have shown the leadership on the volume of services sold by the services sector enterprises to transport and storage enterprises.

To determine the ranking of Ukrainian regions for service potential, it was decided to calculate the average values of its indicators for the analyzed period (see Table 2 in Appendix).
Thus, according to the ranking results of the Ukrainian regions in terms of the level of development of service potential, the leaders are the Kyiv (city), Dnipropetrovsk, Donetsk and Odesa regions (Table 1, lines marked in green), while Chernivtsi, Ternopil and Sumy regions are outsiders (Table 1, lines marked in red).

Using the rating results (see Tables 1-2) the matrix of potentials was formed. Five zones have been allocated on the matrix. Zone 1 combines the best rating indices; it consolidates the leaders of the rating assessments. The zone is determined by the coordinates $[1 ; 5]$ on the $X$ axis (service potential) and the $[1 ; 5]$ on the $\mathrm{Y}$ axis (sales potential). Accordingly, zone 2 is limited to the coordinates $(5 ; 10]$ on both axes; zone $3-(10 ; 15]$ on both axes; zone 4 - $(15 ; 20]$ on both axes; zone 5 - $(20$; 25] on both axes. 


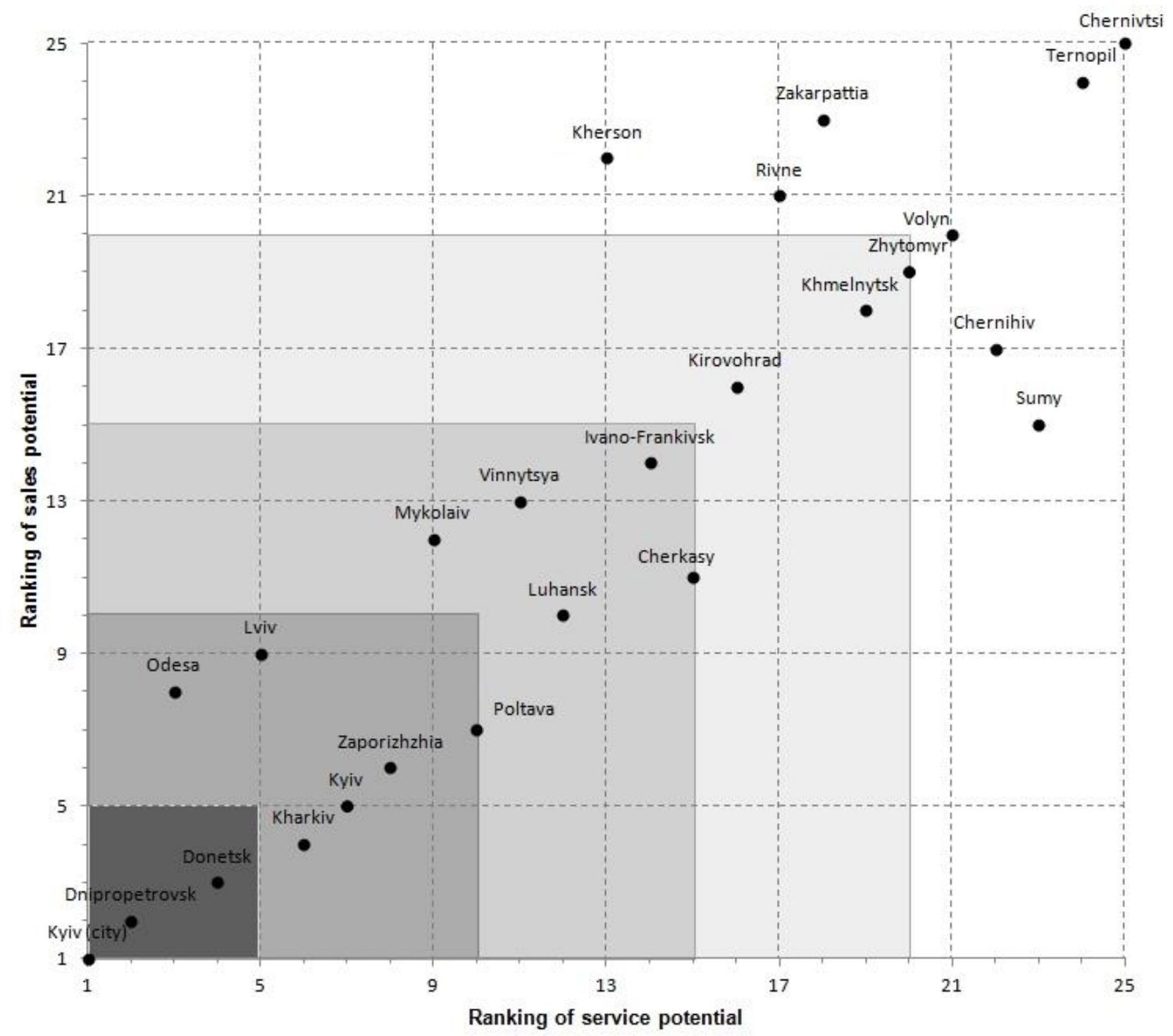

Fig. 13. The matrix of regions' sales and service potentials

High concentration of regions in zones 4 and 5 indicates the crisis processes in the country. This, in

\section{Conclusion}

The aim of this study was to evaluate the service and sales potentials of Ukrainian regions and on the basis of this assessment to describe the degree of regional disparities in the country. In line with this aim, the authors have provided the description of key general characteristics and indicators through which we can determine this potential. The authors state that in the distribution of industrial products, region's sales potential covers the actual and potentially possible sales volumes, which depend on the size of demand for goods, the general market conditions, incomes and business activity, and, in turn, region's service potential brings together intermediaries, the volume of sold services, etc.

On the basis of official statistical information, an estimation of the analyzed potentials of Ukrainian regions for 2010-2015 has been performed. It has turn, should encourage the public and business sector to the active actions.

been shown that almost all regions demonstrate the stability or increase of service and sales potential indicators. Using the indicators' values, the authors have provided the ranking by region. On the majority of the estimated indicators, the leading regions and the outsider regions were identified.

In addition, the authors developed a matrix that reflects the grouping of Ukrainian regions by the levels of sales and service potential. According to the matrix, Chernivtsi and Ternopil regions got in a zone with the worst levels of potentials, while the Kyiv (city), Dnipropetrovsk and Donetsk regions got in a zone with the best levels of potentials. Volyn region has a transitional position and can improve its ratings due to further increase in the volume of services provided by service enterprises, 
and in the volume of retail and wholesale trade turnover. Kherson, Rivne, Zakarpattia, Chernihiv, Sumy and Odesa regions characterized by contradictions in service and sales activities, because of a set of analyzed indicators have significantly different meanings. For instance, Sumy region occupies the $15^{\text {th }}$ place for sales potential, and the $23^{\text {rd }}$ - for service potential; on the contrary, Kherson region $-22^{\text {nd }}$ place for sales processes, and the $13^{\text {th }}$ place in service support. Odeska region has to increase its sales potential (since it ranks the $8^{\text {th }}$

\section{Acknowledgements}

The publication contains the results of studies conducted by President's of Ukraine grant for competitive projects F70 of the State Fund for Fundamental Research place), and maintain the level of service potential (has a leading ranking). Lviv and Mykolaiv regions are also characterized by an insignificant disparities in the development of service and sales potential indicators. In order to ensure effective distribution of industrial products by domestic enterprises and management of distribution channels, it is necessary to take into account the potential risks associated with the disparities of the development of most regions of Ukraine.

("Formation of the management mechanism of products' distribution at the industrial enterprises on the innovative basis", No. SR 0117U001682).

\section{References}

1. Balatskyi, O. F. (2006). Economic potential of administrative and production systems. Sumy: Universytetska knyga.

2. Balatskyi, O. F. (2010). Socio-economic potential of the region. Sumy: Universytetska knyga.

3. Bilovodska, O., Gaidabrus, N., \& Ruban, D. (2017). An analytical study on logistics outsourcing impact on logistical service quality in supply chains (case study: industrial enterprises of Sumy region). Problems and Perspectives in Management, 15(3), 201-211. http://10.21511/ppm.15(3-1).2017.04

4. Fedotov, A. N. (2007). The marketing valuation of the market potential. Scientific Journal of Baikal State University, 2(52), 88-91. Retrieved from http://izvestia.bgu.ru/reader/article.aspx?id=4101

5. Gedz, M. Y. (2012). Essence and structure of social and economic potential of modernization of the regions. Financial space, 2(6), 33-38. Retrieved from https://fp.cibs.ubs.edu.ua/files/1202/12gmjsts.pdf

6. Grishina, L., Efimova, G., \& Grishina, N. (2011). Estimation of economic potential at forming of strategy of his development. The Collection of Scientific Works of Kirovohrad National Technical University. Economic Sciences, 19, 95-101.

7. Khvesyk, M .A., \& Libanova, E. M. (2014). Socio-economic potential of sustainable development of Ukraine and its regions: national report. Retrieved from http://www.nbuv.gov.ua/sites/default/files/nas_dop_2015.pdf

8. Low, S., Henderson, J., \& Weiler, S. (2005). Gauging a Region's Entrepreneurial Potential. Kansas: Federal Reserve Bank of Kansas City Economic Review. Retrieved from https://www.kansascityfed.org/PUBLICAT/ECONREV/PDF/3q05low.pdf

9. Maksimova, I. V. (2009). The market potential of the region as an object of economic planning. Bulletin of the Volgograd State University. Series 3: Economy. Ecology, 2, 96-102. Retrieved from http://cyberleninka.ru/article/n/rynochnyy-potentsial-regiona-kak-obekt-ekonomicheskogo-planirovaniya

10. Official website of the State Statistics Service of Ukraine. Retrieved from http://www.ukrstat.gov.ua/

11. Olefirenko, O., \& Shevliuga, O. (2017). Commercialization of innovations: peculiarities of sales policy at innovation active enterprise. Innovative Marketing, 13(2), 6-12. http://10.21511/im.13(2).2017.01

12. Semenova, V. F., \& Rudenko, O. I. (2012). Study of the level of region's economic potential. Odesa: Odesa national economic university.

13. Teslya, D. V., \& Shults, S. L. (2014). The market potential of the region: essence and its components. Regional economics, 2, 27-37. Retrieved from http://ird.gov.ua/pe/re201402/re201402_027_TeslyaDV,ShultsSL.pdf

14. Tuleja, P., \& Gajdová, K. (2015). Economic Potential of the Regions of the Czech Republic. Journal of Economics, Business and Management, 3(1), 43-47. http://10.7763/JOEBM.2015.V3.153 


\section{Appendix}

Table 1. The average values of sales potential indicators and ranking by region in $2010-2015^{*}$ (developed by the author)

\begin{tabular}{|c|c|c|c|c|c|c|c|c|c|c|c|c|c|c|c|c|}
\hline Region & 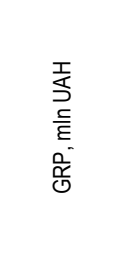 & 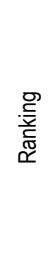 & 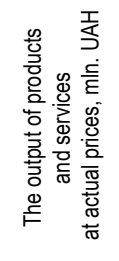 & 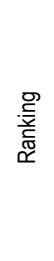 & 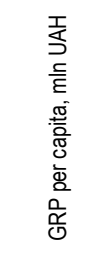 & 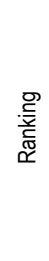 & 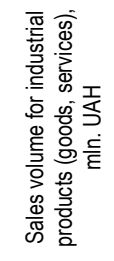 & 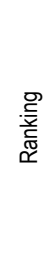 & 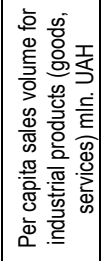 & 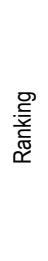 & 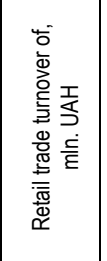 & 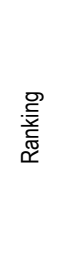 & 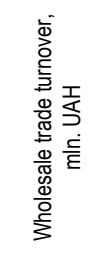 & 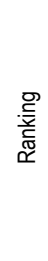 & 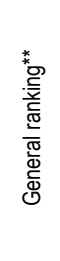 & 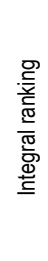 \\
\hline Vinnytsia & 37627.3 & 11 & 86979 & 11 & 23194.2 & 16 & 27798.6 & 12 & 17141.1 & 14 & 24044.3 & 10 & 10435.5 & 17 & 91 & 13 \\
\hline Volyn & 21429.3 & 23 & 47790.3 & 21 & 20596.7 & 19 & 12291.9 & 21 & 11814.0 & 21 & 17617.7 & 15 & 15017.3 & 12 & 132 & 20 \\
\hline Dnipropetrovsk & 158129.5 & 2 & 382500.3 & 2 & 47901 & 2 & 226405.8 & 1 & 68577.6 & 2 & 57388.3 & 3 & 90353.5 & 3 & 15 & 2 \\
\hline Donetsk & 143450.5 & 3 & 369127.5 & 3 & 32800.7 & 6 & 214957.6 & 3 & 49135.4 & 5 & 69892.3 & 2 & 159858.4 & 2 & 24 & 3 \\
\hline Zhytomyr & 26572.7 & 17 & 57751.5 & 17 & 21002.2 & 18 & 17652.7 & 18 & 13953.7 & 19 & 16396.5 & 17 & 7048.0 & 21 & 127 & 19 \\
\hline Zakarpattia & 21538.2 & 22 & 45755.3 & 23 & 17170.7 & 24 & 10152.2 & 23 & 8093.5 & 23 & 15278.7 & 20 & 10611.4 & 16 & 151 & 23 \\
\hline Zaporizhzhia & 59366.2 & 9 & 155004 & 6 & 33377.7 & 5 & 90388.6 & 4 & 50771.5 & 4 & 31547.5 & 7 & 19793.5 & 8 & 43 & 6 \\
\hline Ivano-Frankivsk & 32696.2 & 14 & 71181.2 & 14 & 23667.2 & 14 & 24083.5 & 15 & 17433.4 & 13 & 19054.7 & 12 & 8131.9 & 18 & 100 & 14 \\
\hline Kyiv (city) & 302954.5 & 1 & 629392.0 & 1 & 106175.2 & 1 & 218411.0 & 2 & 76603.4 & 1 & 111614.8 & 1 & 427139.5 & 1 & 8 & 1 \\
\hline Kyiv & 71048.7 & 5 & 165294.7 & 5 & 41199.7 & 4 & 52898.5 & 8 & 30678.1 & 6 & 30399.0 & 8 & 61129.9 & 4 & 40 & 5 \\
\hline Kirovohrad & 25060.7 & 19 & 55120.5 & 18 & 25274.2 & 12 & 16517.9 & 20 & 16658.3 & 15 & 12781 & 23 & 13444.45 & 15 & 122 & 16 \\
\hline Luhansk & 45310.0 & 10 & 116615.3 & 10 & 20029.3 & 22 & 65197.0 & 7 & 29601.1 & 7 & 28323.3 & 9 & 14437.0 & 13 & 78 & 10 \\
\hline Lviv & 64443.7 & 7 & 136395.8 & 9 & 25372.7 & 11 & 37424.7 & 9 & 14407.3 & 17 & 33827.5 & 6 & 37033.8 & 7 & 66 & 9 \\
\hline Mykolaiv & 32754.3 & 13 & 74458.8 & 13 & 27954.8 & 9 & 24671.0 & 14 & 21050.0 & 11 & 17675.0 & 14 & 19013.7 & 9 & 83 & 12 \\
\hline Odesa & 69929.2 & 6 & 151900.8 & 7 & 29571.7 & 8 & 33598.1 & 10 & 14041.4 & 18 & 45684.2 & 5 & 43150.3 & 6 & 60 & 8 \\
\hline Poltava & 62880.8 & 8 & 146423.3 & 8 & 42952.3 & 3 & 80340.5 & 5 & 54838.9 & 3 & 19831.7 & 11 & 16173.6 & 11 & 49 & 7 \\
\hline Rivne & 23826.5 & 20 & 53995.3 & 20 & 20582.5 & 20 & 16922.8 & 19 & 14619.4 & 16 & 13809.3 & 21 & 4631.2 & 24 & 140 & 21 \\
\hline Sumy & 27483.7 & 16 & 62113.5 & 16 & 24143.8 & 13 & 25106.3 & 13 & 22048.8 & 10 & 16106.9 & 18 & 6103.8 & 22 & 108 & 15 \\
\hline Ternopil & 18899.0 & 24 & 41770.5 & 24 & 17570.3 & 23 & 8510.9 & 24 & 7912.3 & 24 & 12234.7 & 24 & 18167.5 & 10 & 153 & 24 \\
\hline Kharkiv & 88522.7 & 4 & 197821.5 & 4 & 32308.2 & 7 & 78464.7 & 6 & 28111.2 & 8 & 52857.5 & 4 & 49911.7 & 5 & 38 & 4 \\
\hline Kherson & 21614.3 & 21 & 46408.3 & 22 & 20088.0 & 21 & 11804.8 & 22 & 10966.5 & 22 & 15414.8 & 19 & 8042.6 & 19 & 146 & 22 \\
\hline Khmelnytsk & 27808.7 & 15 & 63243.0 & 15 & 21211.5 & 17 & 17990.2 & 17 & 13592.5 & 20 & 16716.5 & 16 & 5802.4 & 23 & 123 & 18 \\
\hline Cherkasy & 33837.8 & 12 & 85266.0 & 12 & 26753.3 & 10 & 33564.5 & 11 & 26522.9 & 9 & 17700.8 & 13 & 14222.5 & 14 & 81 & 11 \\
\hline Chernivtsi & 13723.2 & 25 & 28111.0 & 25 & 15123.3 & 25 & 4493.7 & 25 & 4951.8 & 25 & 10632.0 & 25 & 3061.6 & 25 & 175 & 25 \\
\hline Chernihiv & 25244.3 & 18 & 54461.2 & 19 & 23531.3 & 15 & 19179.3 & 16 & 17881.2 & 12 & 13623.3 & 22 & 7366.8 & 20 & 122 & 17 \\
\hline
\end{tabular}

* - the lines marked in green show the best integral values of the region's indicators; and the lines marked in red show the regions with worst indicators' values;

** - calculated as the sum of ratings for each indicator. 
Table 2 . The average values of service potential indicators and ranking by region in $2010-2015^{*}$ (developed by the author)

\begin{tabular}{|c|c|c|c|c|c|c|c|c|c|c|c|c|c|c|}
\hline Regions & 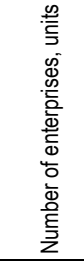 & 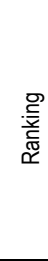 & 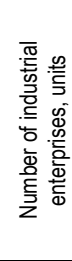 & 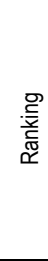 & 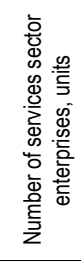 & 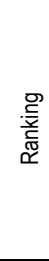 & 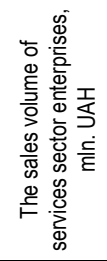 & 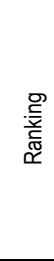 & 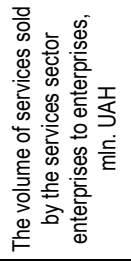 & 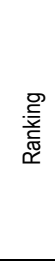 & 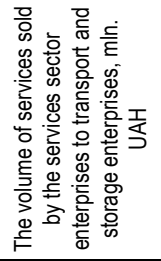 & 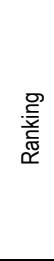 & 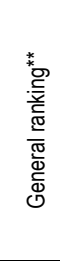 & 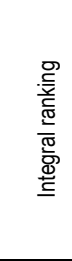 \\
\hline Vinnytsia & 8816 & 11 & 1356 & 12 & 1288 & 15 & 4739.1 & 10 & 2475.5 & 13 & 1413 & 10 & 71 & 11 \\
\hline Volyn & 5317 & 22 & 725 & 24 & 1096 & 21 & 2882.4 & 18 & 1840.8 & 16 & 931.4 & 17 & 118 & 21 \\
\hline Dnipropetrovsk & 27214 & 2 & 3249 & 4 & 4927 & 3 & 19436.7 & 4 & 13782.9 & 4 & 6037.5 & 3 & 20 & 2 \\
\hline Donetsk & 22689 & 5 & 3257 & 3 & 5426 & 2 & 19674.5 & 3 & 13792.1 & 3 & 4957.8 & 5 & 21 & 3-4 \\
\hline Zhytomyr & 6435 & 18 & 1440 & 10 & 1176 & 19 & 2791.5 & 19 & 1098.2 & 23 & 381.0 & 24 & 113 & $19-20$ \\
\hline Zakarpattia & 5867 & 19 & 938 & 18 & 1246 & 17 & 2767.5 & 20 & 1585.4 & 19 & 922.6 & 18 & 111 & 18 \\
\hline Zaporizhzhia & 14585 & 8 & 1931 & 8 & 2897 & 7 & 6323.9 & 9 & 4055.8 & 9 & 1474.0 & 9 & 50 & 8 \\
\hline Ivano-Frankivsk & 7810 & 13 & 1424 & 11 & 1366 & 14 & 2902.8 & 17 & 1654.24 & 18 & 976.14 & 16 & 89 & 14 \\
\hline Kyiv (city) & 85958 & 1 & 7472 & 1 & 8314 & 1 & 116778 & 1 & 81852.6 & 1 & 15631.7 & 2 & 7 & 1 \\
\hline Kyiv & 17326 & 7 & 2795 & 6 & 2279 & 8 & 11625.6 & 7 & 7915.0 & 7 & 4078.6 & 7 & 42 & 7 \\
\hline Kirovohrad & 7191 & 16 & 868 & 22 & 978 & 24 & 3767.94 & 14 & 2925.4 & 10 & 2460.5 & 8 & 94 & 16 \\
\hline Luhansk & 8447 & 12 & 1517 & 9 & 2035 & 9 & 4382.0 & 11 & 2553.5 & 12 & 884.6 & 19 & 72 & 12 \\
\hline Lviv & 18387 & 6 & 2816 & 5 & 4297 & 6 & 14883.8 & 5 & 9809.4 & 5 & 5093.1 & 4 & 31 & 5 \\
\hline Mykolaiv & 10283 & 9 & 1122 & 15 & 1891 & 10 & 7044.2 & 8 & 5399.7 & 8 & 4187.1 & 6 & 56 & 9 \\
\hline Odesa & 24506 & 4 & 2372 & 7 & 4896 & 5 & 28618.3 & 2 & 23061.6 & 2 & 17607.2 & 1 & 21 & $3-4$ \\
\hline Poltava & 9873 & 10 & 1244 & 13 & 1782 & 11 & 4324.5 & 12 & 2873.2 & 11 & 1407.7 & 11 & 68 & 10 \\
\hline Rivne & 5090 & 23 & 876 & 21 & 1247 & 16 & 2946.6 & 16 & 1679.1 & 17 & 1131.7 & 14 & 107 & 17 \\
\hline Sumy & 5619 & 21 & 818 & 23 & 1194 & 18 & 2713.3 & 22 & 1450.7 & 20 & 772.0 & 20 & 124 & 23 \\
\hline Ternopil & 5000 & 24 & 913 & 19 & 1037 & 23 & 2023.0 & 24 & 1090.9 & 24 & 554.0 & 23 & 137 & 24 \\
\hline Kharkiv & 25389 & 3 & 3830 & 2 & 4908 & 4 & 13223.2 & 6 & 8477.9 & 6 & 1403.5 & 12 & 33 & 6 \\
\hline Kherson & 7637 & 15 & 953 & 17 & 1696 & 12 & 3113.7 & 15 & 2020.9 & 15 & 1277.0 & 13 & 87 & 13 \\
\hline Khmelnytsk & 6728 & 17 & 1114 & 16 & 1367 & 13 & 2308.9 & 23 & 1143.4 & 22 & 570.9 & 22 & 113 & $19-20$ \\
\hline Cherkasy & 7666 & 14 & 1150 & 14 & 1087 & 22 & 4290.1 & 13 & 2113.5 & 14 & 1060.8 & 15 & 92 & 15 \\
\hline Chernivtsi & 4220 & 25 & 598 & 25 & 853 & 25 & 1549.8 & 25 & 617.8 & 25 & 251.2 & 25 & 150 & 25 \\
\hline Chernihiv & 5808 & 20 & 901 & 20 & 1102 & 20 & 2751.6 & 21 & 1274.1 & 21 & 673.3 & 21 & 123 & 22 \\
\hline
\end{tabular}

* - the lines marked in green show the best integral values of the region's indicators; and the lines marked in red show the regions with worst indicators' values;

** - calculated as the sum of ratings for each indicator. 